\title{
BOND MARKET DEVELOPMENT IN DEVELOPING ASIA
}

John D. Burger, Francis E. Warnock, and Veronica Cacdac Warnock

NO. 448

August 2015
ADB ECONOMICS WORKING PAPER SERIES 


\section{ADB Economics Working Paper Series}

\section{Bond Market Development in Developing Asia}

John D. Burger, Francis E. Warnock, and Veronica Cacdac Warnock

No. 448 | August 2015
John Burger (JBurger@loyola.edu) is Professor of Economics at the Sellinger School of Business, Loyola University Maryland. Francis E. Warnock

(warnockf@darden.virginia.edu) is the James C. Wheat, Jr. Professor of Business Administration at the Darden School of Business, University of Virginia. Veronica Cacdac Warnock (warnockm@darden.virginia.edu) is Senior Lecturer and Batten Institute Fellow at the Darden School of Business, University of Virginia.

This paper was prepared as a background paper for the Asian Development Outlook 2015. 
Asian Development Bank

6 ADB Avenue, Mandaluyong City

1550 Metro Manila, Philippines

www.adb.org

(C) 2015 by Asian Development Bank

August 2015

ISSN 2313-6537 (Print), 2313-6545 (e-ISSN)

Publication Stock No. WPS157595-2

The views expressed in this paper are those of the authors and do not necessarily reflect the views and policies of the Asian Development Bank (ADB) or its Board of Governors or the governments they represent.

ADB does not guarantee the accuracy of the data included in this publication and accepts no responsibility for any consequence of their use.

By making any designation of or reference to a particular territory or geographic area, or by using the term "country" in this document, $A D B$ does not intend to make any judgments as to the legal or other status of any territory or area.

Note: In this publication, "\$” refers to US dollars.

The ADB Economics Working Paper Series is a forum for stimulating discussion and eliciting feedback on ongoing and recently completed research and policy studies undertaken by the Asian Development Bank (ADB) staff, consultants, or resource persons. The series deals with key economic and development problems, particularly those facing the Asia and Pacific region; as well as conceptual, analytical, or methodological issues relating to project/program economic analysis, and statistical data and measurement. The series aims to enhance the knowledge on Asia's development and policy challenges; strengthen analytical rigor and quality of ADB's country partnership strategies, and its subregional and country operations; and improve the quality and availability of statistical data and development indicators for monitoring development effectiveness.

The ADB Economics Working Paper Series is a quick-disseminating, informal publication whose titles could subsequently be revised for publication as articles in professional journals or chapters in books. The series is maintained by the Economic Research and Regional Cooperation Department. 


\section{CONTENTS}

TABLES AND FIGURES $\quad$ iv

ABSTRACT $v$

$\begin{array}{ll}\text { I. INTRODUCTION } & 1\end{array}$

II. $\quad$ FINANCIAL SYSTEMS IN DEVELOPING ASIA 1

III. STRUCTURE OF BOND MARKETS AROUND THE WORLD 4

IV. FACTORS AFFECTING THE SIZE OF BOND MARKETS IN EMERGING
MARKET ECONOMIES

A. Determinants 9

B. Caveats 11

V. INSIGHTS INTO DEVELOPING ASIA'S BOND MARKETS 12

$\begin{array}{lll}\text { VI. CONCLUSION } & 17\end{array}$

$\begin{array}{lr}\text { REFERENCES } & 19\end{array}$ 


\section{TABLES AND FIGURES}

\section{TABLES}

$1 \quad$ Financial Structure around the World, 2011

$2 \quad$ Financial Structure in Developing Asia, 2011

3 Bond Market Characteristics: Summary Statistics by Region, end of 2011

4 Bond Market Development According to Bank for International Settlements Data 6

5 Developing Asian Bond Markets and Fundamental Factors 16

\section{FIGURES}

1 The Structure of Global Bond Markets 8

2 Two Fundamental Determinants of Local Bond Market Development 10

3 Emerging Asian Bond Markets 13

4 Maturity Structure of Sovereign Local Currency Bonds: Philippines and Viet Nam 15

5 Inflation Volatility versus Bond Market Development in Developing Asia 15 


\begin{abstract}
We describe and assess two dimensions of the current state of bond market development in developing Asia: the role of bond markets in overall financial systems and a comparison of the salient features of bond market development in developing Asia and other regions. We highlight key drivers and constraints of bond market development in developing Asia, particularly in smaller economies, as well as key implications for policymakers, especially for promoting bond market development in the region. Our analysis suggests that high inflation volatility presents a serious obstacle to bond market development. We find that smaller developing Asian economies could enable bond market development by pursuing creditor friendly policies and strengthening the legal rights of borrowers.
\end{abstract}

Keywords: bond market, financial development, financial system

JEL Classification: G10, G15, F30 


\section{INTRODUCTION}

A decade ago emerging market economy (EME) local currency markets were small-and some might say irrelevant. Many doubted that local bond markets in EMEs would ever develop. One aspect of this thinking was the "original sin" hypothesis, which, in its strongest form, suggests that EMEs would forever have small, inconsequential bond markets. ${ }^{1}$ The proposition is that small economies have an innate condition that precludes the development of a local bond market no matter how hard they try, whatever policies they put in place or institutions they develop.

The past decade saw a strong rejection of this hypothesis. A wide range of EMEs have indeed been able to grow their local currency bond markets, both in raw size and relative to gross domestic product (GDP). This paper describes the structure of financial systems (banking systems, and stock and bond markets) in Asia and, to provide a point of comparison, in other regions. It examines the development of bond markets using two global databases (one from the Bank for International Settlements [BIS] and one from the World Bank) and one database on developing Asia (from the Asian Development Bank [ADB]). ${ }^{2}$ The paper draws on knowledge acquired from past analyses of bond market development to suggest ways smaller developing Asian economies can develop their markets.

Bond markets have positive externalities with respect to economic growth, financial inclusion, and financial stability. They represent an important component of a diversified finance sector. On a macro level, financial development has been linked to economic growth and poverty reduction (Levine $2005,2008)$. On financial inclusion, the core factors that enable bond market development are the same factors that enable borrowing and lending within an economy (Burger and Warnock 2006). In a region in which $70 \%$ of households in one of the largest developing countries (the Philippines) do not have formal bank accounts, anything that improves financial inclusion should be a priority. Finally, and perhaps most directly, the growth in EME bond markets that this paper documents has likely improved financial stability, as EMEs are now much less reliant on foreign currency-denominated bonds, which can result in currency mismatches and are susceptible to depreciation-related crises. The development of local currency bond markets and the concomitant reduction in reliance on foreign currency borrowing is a fundamental-and positive-change in the structure of EME financial systems. EME financial systems are more resilient now that the currency mismatches of the past have been greatly reduced, and this improved financial stability extends to the global economy, as the lack of reliable financial instruments in EMEs drove flows to developed markets and helped spark the global financial crisis, as Caballero, Fahri, and Gourinchas (2008) note. The development of local currency bond markets should thus improve financial stability in individual economies and perhaps increase global financial stability.

\section{FINANCIAL SYSTEMS IN DEVELOPING ASIA}

We first place developing Asia's bond markets in the context of their overall financial systems and compare those systems with systems in other regions, using 2011 data from the World Bank's financial structure database (Beck, Demirgüç-Kunt, and Levine 2000, 2009; Čihák et al. 2012). For developing Asia as a whole, the banking system has deposits equivalent to $60 \%$ of GDP, stock market capitalization is $71 \%$ of GDP, total public bonds are worth $26 \%$ of GDP, and total private bonds are

\footnotetext{
On the original sin hypothesis, see Eichengreen and Hausmann $(1999,2005)$, among others. The view has since evolved to a much narrower form: the unlikelihood of any small country currency ever becoming truly international.

2 Developing Asia refers to the 45 developing member countries of ADB.
} 
worth $20 \%$ of GDP (Table 1). Variation within the region is large, with much lower figures in Central Asia and the Pacific.

Developing Asia's banking systems, and stock and bond markets are on average larger than those of other developing regions and high-income countries that are not members of the Organisation for Economic Co-operation and Development (OECD). Compared with OECD members, developing Asia's banking system and especially its bond markets are small.

Table 1: Financial Structure around the World, 2011

\begin{tabular}{lccrc}
\hline \multicolumn{1}{c}{ Economy } & $\begin{array}{c}\text { Banking } \\
\text { System }\end{array}$ & $\begin{array}{c}\text { Stock } \\
\text { Market }\end{array}$ & $\begin{array}{r}\text { Public } \\
\text { Bonds }\end{array}$ & $\begin{array}{c}\text { Private } \\
\text { Bonds }\end{array}$ \\
\hline Developing Asia & 60.0 & 71.0 & 25.7 & 20.4 \\
Central Asia & 23.1 & 25.0 & 0.0 & 0.0 \\
East Asia & 60.1 & 73.4 & 25.9 & 27.8 \\
South Asia & 57.0 & 60.3 & 27.0 & 4.0 \\
Southeast Asia & 67.9 & 77.7 & 28.3 & 11.8 \\
The Pacific & 44.5 & 54.1 & 0.0 & 0.0 \\
Rest of the world, developing & 43.5 & 41.5 & 18.4 & 8.5 \\
Europe and Central Asia & 42.7 & 23.6 & 17.5 & 0.8 \\
Latin America and the Caribbean & 41.9 & 45.5 & 25.2 & 13.5 \\
Middle East and North Africa & 67.4 & 12.5 & 1.9 & 0.0 \\
Sub-Saharan Africa & 38.4 & 72.1 & 8.7 & 5.2 \\
High income & 104.3 & 81.3 & 78.7 & 53.0 \\
OECD members & 110.2 & 84.3 & 85.3 & 57.6 \\
Non-OECD members & 41.2 & 46.7 & 2.8 & 0.0 \\
\hline
\end{tabular}

OECD = Organisation for Economic Co-operation and Development.

Note: Reported are the size of the banking system (measured as the amount of deposits), stock market capitalization, and public and private bonds outstanding, all expressed as a percentage of gross domestic product (GDP). Regional averages are GDP weighted.

Source: Authors' calculations using data from Beck, Demirgüç-Kunt, and Levine (2000, 2009); and Čihák et al. 2012.

Central Asia and the Pacific have underdeveloped financial systems (Table 2). No country in either region has a bond market, and many countries in both regions have no stock markets. Funding in Central Asia and the Pacific comes largely through the banking system.

Kazakhstan has the largest financial system in Central Asia, with bank deposits worth 28\% of GDP and a stock market worth 29\% of GDP. The financial systems of other countries in the subregion are much smaller. No country in Central Asia has a public or private bond market of any size, at least according to World Bank data on bond markets.

Papua New Guinea's stock market is large relative to its GDP (80\%). No other country in the Pacific has a significant stock market, and the banking systems in the subregion are small, with the exception of Vanuatu's (73\% of GDP). 
Table 2: Financial Structure in Developing Asia, 2011

\begin{tabular}{|c|c|c|c|c|}
\hline Economy & $\begin{array}{l}\text { Banking } \\
\text { System }\end{array}$ & $\begin{array}{c}\text { Stock } \\
\text { Market }\end{array}$ & $\begin{array}{l}\text { Public } \\
\text { Bonds }\end{array}$ & $\begin{array}{l}\text { Private } \\
\text { Bonds }\end{array}$ \\
\hline Developing Asia & 60.0 & 71.0 & 25.7 & 20.4 \\
\hline Central Asia & 23.1 & 25.0 & 0.0 & 0.0 \\
\hline Armenia & 18.1 & 0.3 & 0.0 & 0.0 \\
\hline Azerbaijan & 11.7 & - & 0.0 & 0.0 \\
\hline Georgia & 21.9 & 6.8 & 0.0 & 0.0 \\
\hline Kazakhstan & 27.5 & 28.5 & 0.0 & 0.0 \\
\hline Kyrgyz Republic & - & 2.1 & 0.0 & 0.0 \\
\hline Tajikistan & - & - & 0.0 & 0.0 \\
\hline Turkmenistan & - & - & 0.0 & 0.0 \\
\hline Uzbekistan & - & - & 0.0 & 0.0 \\
\hline East Asia & 60.1 & 73.4 & 25.9 & 27.8 \\
\hline People's Republic of China & 49.9 & 58.8 & 22.4 & 23.1 \\
\hline Hong Kong, China & 301.6 & 396.8 & 36.0 & 15.3 \\
\hline Republic of Korea & 72.1 & 96.2 & 44.8 & 59.3 \\
\hline Mongolia & 46.5 & 15.9 & 0.0 & 0.0 \\
\hline South Asia & 57.0 & 60.3 & 27.0 & 4.0 \\
\hline Afghanistan & 15.7 & 0.0 & 0.0 & 0.0 \\
\hline Bangladesh & 49.5 & 17.3 & 0.0 & 0.0 \\
\hline Bhutan & 60.1 & 0.0 & 0.0 & 0.0 \\
\hline India & 62.0 & 69.7 & 29.6 & 4.9 \\
\hline Maldives & 79.3 & 0.0 & 0.0 & 0.0 \\
\hline Nepal & 58.7 & 25.3 & 0.0 & 0.0 \\
\hline Pakistan & 27.5 & 16.9 & 30.7 & 0.0 \\
\hline Sri Lanka & 31.6 & 33.8 & 0.0 & 0.0 \\
\hline Southeast Asia & 67.9 & 77.7 & 28.3 & 11.8 \\
\hline Brunei Darussalam & 60.4 & 0.0 & 0.0 & 0.0 \\
\hline Cambodia & 32.0 & 0.0 & 0.0 & 0.0 \\
\hline Indonesia & 32.0 & 45.1 & 10.8 & 1.4 \\
\hline Lao PDR & - & 0.0 & 0.0 & 0.0 \\
\hline Malaysia & 120.9 & 144.1 & 54.0 & 58.1 \\
\hline Myanmar & - & 0.0 & 0.0 & 0.0 \\
\hline Philippines & 51.3 & 73.9 & 29.1 & 1.0 \\
\hline Singapore & 125.8 & 148.1 & 45.4 & 10.0 \\
\hline Thailand & 99.7 & 81.7 & 49.8 & 12.7 \\
\hline Viet Nam & 12.2 & 15.4 & 0.0 & 0.0 \\
\hline The Pacific & 44.5 & 54.1 & 0.0 & 0.0 \\
\hline Fiji & 51.8 & 38.4 & 0.0 & 0.0 \\
\hline Kiribati & - & 0.0 & 0.0 & 0.0 \\
\hline Marshall Islands & - & 0.0 & 0.0 & 0.0 \\
\hline Federated States of Micronesia & - & 0.0 & 0.0 & 0.0 \\
\hline Palau & - & 0.0 & 0.0 & 0.0 \\
\hline Papua New Guinea & 43.1 & 79.7 & 0.0 & 0.0 \\
\hline Samoa & 44.7 & 0.0 & 0.0 & 0.0 \\
\hline Solomon Islands & 30.2 & 0.0 & 0.0 & 0.0 \\
\hline Timor-Leste & 29.1 & 0.0 & 0.0 & 0.0 \\
\hline Tonga & 38.1 & 0.0 & 0.0 & 0.0 \\
\hline Tuvalu & - & 0.0 & 0.0 & 0.0 \\
\hline Vanuatu & 73.1 & 0.0 & 0.0 & 0.0 \\
\hline
\end{tabular}

- = data not available, Lao PDR = Lao People's Democratic Republic.

Notes: Reported are the size of the banking system (measured as the amount of deposits), stock market capitalization, and public and private bonds outstanding, all expressed as a percentage of gross domestic product (GDP). Regional averages are GDP weighted. Excluded in the table due to lack of data are three developing Asian economies: Cook Islands; Nauru; and Taipei,China.

Source: Authors' calculations using data from Beck, Demirgüç-Kunt, and Levine (2000, 2009); and Čihák et al. 2012. 
The finance sectors in the three other subregions in Asia-East Asia, Southeast Asia, and South Asia-are much more developed. The finance sector of East Asia is well developed. Only Mongolia lags, with a financial structure that is much more like that of a Central Asian economy. East Asia dominates developing Asia, with $64 \%$ of overall regional economic activity. Within East Asia, the People's Republic of China (PRC) accounts for $83 \%$ of activity. The PRC has a banking system that has deposits worth $50 \%$ of GDP, a stock market that is worth $59 \%$ of GDP, and public and private bond markets that are worth $22 \%$ and $23 \%$ of GDP, respectively. Hong Kong, China has a very large banking system (302\% of GDP) and stock market (397\% of GDP). The Republic of Korea has the most developed and balanced finance sector, with a substantial banking system (72\% of GDP) and stock market ( $96 \%$ of GDP). Its sovereign bond market, worth 45\% of GDP, is the largest in the subregion (and the third largest in developing Asia, after Malaysia and Thailand), and its corporate bond market, worth $59 \%$ of GDP, is the largest in all of developing Asia.

In Southeast Asia, Malaysia has the most developed financial system, with a sizable banking sector (121\%) and stock market (144\%). Its public bond market (54\% of GDP) is developing Asia's largest, and its private bond market (58\%) the second largest, after the Republic of Korea.

India dominates South Asia, with a banking system, stock market, and public bond market that are on a par with the averages in developing East Asia. In contrast, India's corporate bond market is small (5\% of GDP). Other countries in South Asia are less developed financially. Other than India, Pakistan is the subregion's only country with a bond market.

In sum, in many of the larger economies in the region, banking systems and stock markets are well developed, albeit not at OECD levels, whereas public and private bond markets are underdeveloped. In contrast, the median economy in developing Asia has a banking system whose deposits represent $47 \%$ of GDP, a stock market whose capitalization is just $4 \%$ of GDP, and no sovereign or corporate bond market.

\section{STRUCTURE OF BOND MARKETS AROUND THE WORLD}

Because of data limitations, this section includes data on only 46 economies, including just a small subset of developing Asia's larger economies (the PRC, India, Indonesia, Malaysia, Pakistan, the Philippines, and Thailand). Although it covers fewer economies, the analysis is useful because it helps place some of Asia's larger EME bond markets in the context of bond markets around the world.

Table 3 presents information on the size and composition of global bond markets as of 2011 . Table 4 presents selected data on individual economies. ${ }^{3}$

The BIS data are compiled from multiple sources and are built from two complementary databases on the value of outstanding local and foreign currency bonds. Given that the BIS changed its methodology in 2012 (see Gruić and Wooldridge 2012) and more recent data may not be consistent with the historical data, the data in Tables 3 and 4 end in 2011. The following description refers to the pre-2012 BIS methodology.

\footnotetext{
3 Unlike Tables 1 and 2, which come from the World Bank's financial structure database, Tables 3 and 4 are built from Bank for International Settlements (BIS) databases on domestic and international bonds. One would hope that both databases would provide identical information on bond markets, but bond market data are not as readily available as stock market data, and some discrepancies are likely.
} 
Table 3: Bond Market Characteristics: Summary Statistics by Region, end of 2011

\begin{tabular}{|c|c|c|c|c|c|c|c|c|}
\hline \multirow[b]{2}{*}{ Economy } & \multirow{2}{*}{$\begin{array}{l}\text { Total } \\
\text { \$ billion }\end{array}$} & \multicolumn{4}{|c|}{ Local Currency Denominated } & \multicolumn{3}{|c|}{ US Dollar Denominated } \\
\hline & & $\$$ billion & $\%$ of GDP & $\%$ of total & $\begin{array}{c}\% \\
\text { govern- } \\
\text { ment }\end{array}$ & $\$$ billion & $\begin{array}{l}\% \text { of } \\
\text { total }\end{array}$ & $\begin{array}{c}\% \\
\text { govern- } \\
\text { ment }\end{array}$ \\
\hline \multicolumn{9}{|c|}{ Advanced economies } \\
\hline Total & 74,371 & 67,912 & 164 & 91 & 49 & 31,403 & 42 & 37 \\
\hline Eurozone & 22,106 & 20,147 & 157 & 91 & 39 & 1,071 & 5 & 7 \\
\hline Other & 22,857 & 19,134 & 140 & 84 & 72 & 1,702 & 7 & 6 \\
\hline United States & 29,409 & 28,630 & 191 & 97 & 40 & 28,630 & 97 & 40 \\
\hline \multicolumn{9}{|c|}{ Emerging market economies } \\
\hline Total & 8,119 & 7,070 & 32 & 87 & 59 & 770 & 9 & 37 \\
\hline Europe & 699 & 500 & 24 & 72 & 89 & 68 & 10 & 88 \\
\hline Latin America & 1,406 & 1,053 & 22 & 75 & 80 & 302 & 21 & 44 \\
\hline Asia & 5,667 & 5,260 & 41 & 93 & 50 & 326 & 6 & 18 \\
\hline Other & 347 & 255 & 11 & 74 & 75 & 75 & 22 & 49 \\
\hline
\end{tabular}

GDP = gross domestic product, US = United States.

Notes: Local currency-denominated debt is the sum of the local currency portion of BIS Table 14B and the long-term debt component from Table 16A. The amount of United States dollar-denominated debt is calculated from Table 14B. Groupings for the economies follow the International Monetary Fund classifications of "advanced economies" and "other emerging market and developing economies" with the exceptions of Hong Kong, China; the Republic of Korea; and Singapore which are grouped under EMEs (i.e., developing Asia following ADB classification). See Table 4 for economies included in the aggregates.

Source: Authors' calculations using BIS and IMF 2013.

One BIS data set is on domestic debt, which the BIS defines as local currency bonds issued by local firms in the local market. These data appear in Table 16A (Domestic Debt Securities) of the BIS Quarterly Review, but that table includes debt securities of all maturities, including very short maturity "bills" and commercial paper. Because the focus here is on bonds (defined as debt securities with original maturity of at least 1 year), we obtained the data underlying Table $16 \mathrm{~A}$ to separate short-term bills and commercial paper from long-term debt securities.

The other BIS data set is on international bonds-bonds issued either in a different currency or a different market. We obtained the underlying security-level data from Table 14B (International Bonds and Notes by Country of Residence) of the BIS Quarterly Review (which does not present issuance by currency by country) in order to calculate our own aggregates.

With these two sources (and our calculations), local currency-denominated debt is the sum of the long-term debt component of domestic debt and the local currency/local issuer portion of international bonds. US dollar-denominated debt is the dollar portion of international bonds. Our measures include all bonds issued by all types of issuers (government and private). 
Table 4: Bond Market Development According to Bank for International Settlements Data

\begin{tabular}{|c|c|c|c|c|c|c|c|c|}
\hline \multirow[b]{2}{*}{ Economy } & \multirow{2}{*}{$\begin{array}{l}\text { Total } \\
\text { (2011) } \\
\$ \text { billion }\end{array}$} & \multicolumn{7}{|c|}{ Local Currency Denominated } \\
\hline & & $\begin{array}{c}2011 \\
\$ \text { billion }\end{array}$ & $\%$ of GDP & $\%$ of total & $\begin{array}{c}2006 \\
\% \text { of GDP }\end{array}$ & $\%$ of total & $\begin{array}{c}2001 \\
\% \text { of GDP }\end{array}$ & $\%$ of total \\
\hline Advanced economies & 74,371 & 67,912 & 164 & 91 & 134 & 91 & 107 & 93 \\
\hline Eurozone AEs & 22,106 & 20,147 & 157 & 91 & 133 & 91 & 94 & 89 \\
\hline Austria & 672 & 588 & 141 & 88 & 132 & 82 & 90 & 74 \\
\hline Belgium & 765 & 747 & 145 & 98 & 104 & 97 & 118 & 96 \\
\hline Finland & 193 & 149 & 57 & 77 & 53 & 85 & 41 & 72 \\
\hline France & 4,397 & 4,012 & 145 & 91 & 112 & 92 & 82 & 91 \\
\hline Germany & 4,269 & 3,792 & 105 & 89 & 119 & 91 & 96 & 92 \\
\hline Greece & 556 & 550 & 190 & 99 & 107 & 97 & 74 & 89 \\
\hline Ireland & 1,259 & 1,020 & 470 & 81 & 285 & 78 & 46 & 65 \\
\hline Italy & 4,021 & 3,953 & 180 & 98 & 147 & 97 & 114 & 96 \\
\hline Netherlands & 2,817 & 2,265 & 271 & 80 & 241 & 81 & 165 & 74 \\
\hline Portugal & 400 & 396 & 167 & 99 & 88 & 98 & 57 & 89 \\
\hline Spain & 2,756 & 2,676 & 181 & 97 & 135 & 97 & 53 & 92 \\
\hline Other AEs & 22,857 & 19,134 & 140 & 84 & 104 & 81 & 84 & 87 \\
\hline Australia & 1,216 & 777 & 56 & 64 & 41 & 51 & 30 & 55 \\
\hline Canada & 1,957 & 1,527 & 88 & 78 & 65 & 77 & 69 & 72 \\
\hline Denmark & 840 & 704 & 211 & 84 & 194 & 86 & 160 & 90 \\
\hline Iceland & 41 & 19 & 132 & 45 & 358 & 58 & 78 & 63 \\
\hline Japan & 12,331 & 12,253 & 209 & 99 & 158 & 99 & 108 & 99 \\
\hline New Zealand & 64 & 46 & 29 & 72 & 17 & 57 & 22 & 64 \\
\hline Norway & 430 & 220 & 45 & 51 & 33 & 52 & 27 & 54 \\
\hline Sweden & 745 & 449 & 83 & 60 & 72 & 65 & 57 & 63 \\
\hline Switzerland & 327 & 312 & 47 & 95 & 55 & 95 & 58 & 97 \\
\hline United Kingdom & 4,907 & 2,827 & 115 & 58 & 65 & 52 & 46 & 62 \\
\hline United States & 29,409 & 28,630 & 191 & 97 & 158 & 96 & 131 & 98 \\
\hline EMEs & 8,119 & 7,070 & 32 & 87 & 31 & 83 & 26 & 75 \\
\hline Europe & 699 & 500 & 24 & 72 & 30 & 77 & 25 & 76 \\
\hline Croatia & 18 & 10 & 15 & 52 & 13 & 49 & 9 & 33 \\
\hline Czech Republic & 97 & 74 & 34 & 76 & 29 & 88 & 14 & 85 \\
\hline Hungary & 75 & 39 & 28 & 52 & 46 & 66 & 28 & 60 \\
\hline Poland & 223 & 161 & 31 & 72 & 34 & 77 & 20 & 86 \\
\hline Slovakia & 36 & 22 & 23 & 61 & 23 & 81 & 18 & 68 \\
\hline Turkey & 249 & 195 & 25 & 78 & 27 & 80 & 36 & 78 \\
\hline Latin America & 1,406 & 1,053 & 22 & 75 & 20 & 70 & 19 & 54 \\
\hline Argentina & 93 & 38 & 8 & 40 & 30 & 50 & 14 & 29 \\
\hline Brazil & 582 & 456 & 18 & 78 & 15 & 69 & 20 & 59 \\
\hline Chile & 105 & 79 & 32 & 75 & 24 & 72 & 42 & 77 \\
\hline Colombia & 107 & 86 & 26 & 80 & 28 & 76 & 19 & 61 \\
\hline Mexico & 477 & 370 & 32 & 78 & 24 & 78 & 17 & 59 \\
\hline Peru & 41 & 24 & 14 & 59 & 12 & 54 & 12 & 60 \\
\hline Asia & 5,667 & 5,260 & 41 & 93 & 39 & 90 & 33 & 88 \\
\hline $\begin{array}{l}\text { People's Republic } \\
\text { of China }\end{array}$ & 2,956 & 2,938 & 40 & 99 & 27 & 98 & 18 & 95 \\
\hline Hong Kong, China & 116 & 45 & 18 & 39 & 19 & 53 & 15 & 54 \\
\hline India & 515 & 489 & 26 & 95 & 30 & 95 & 25 & 97 \\
\hline
\end{tabular}




\begin{tabular}{|c|c|c|c|c|c|c|c|c|}
\hline \multirow[b]{2}{*}{ Economy } & \multirow{2}{*}{$\begin{array}{l}\text { Total } \\
(2011) \\
\$ \text { billion }\end{array}$} & \multicolumn{7}{|c|}{ Local Currency Denominated } \\
\hline & & $\begin{array}{c}2011 \\
\$ \text { billion }\end{array}$ & $\%$ of GDP & $\%$ of total & $\begin{array}{c}2006 \\
\% \text { of GDP }\end{array}$ & $\%$ of total & $\begin{array}{c}2001 \\
\% \text { of GDP }\end{array}$ & $\%$ of tota \\
\hline Indonesia & 113 & 84 & 10 & 74 & 15 & 87 & 27 & 96 \\
\hline Republic of Korea & 1,265 & 1,117 & 100 & 88 & 94 & 91 & 85 & 91 \\
\hline Malaysia & 260 & 233 & 81 & 90 & 59 & 79 & 57 & 77 \\
\hline Pakistan & 34 & 32 & 15 & 94 & 15 & 90 & 22 & 96 \\
\hline Philippines & 101 & 63 & 28 & 62 & 26 & 50 & 21 & 48 \\
\hline Singapore & 130 & 90 & 37 & 69 & 40 & 60 & 35 & 69 \\
\hline Thailand & 175 & 170 & 49 & 97 & 37 & 89 & 28 & 80 \\
\hline Other EMEs & 347 & 255 & 11 & 74 & 11 & 69 & 10 & 50 \\
\hline Russian Federation & 156 & 91 & 5 & 59 & 3 & 41 & 2 & 13 \\
\hline South Africa & 191 & 164 & 40 & 86 & 39 & 90 & 32 & 87 \\
\hline
\end{tabular}

$\mathrm{AEs}=$ advanced economies, $\mathrm{EMEs}=$ emerging market economies

Note: The amount of United States dollar denominated debt is calculated from Table 14B. Country groupings follow International Monetary Fund classifications of "advanced economies" and "other emerging market and developing economies" with the exceptions of Hong Kong, China; the Republic of Korea; and Singapore which are grouped under EMEs (i.e., developing Asia following ADB classification).

Source: Authors' calculations using BIS and IMF 2013.

Some features of Tables 3 and 4 are worth noting:

(i) The past decade witnessed extraordinary growth in the size of global bond markets. At the end of 2011, the global bond market was worth $\$ 82.5$ trillion, almost three times its value in 2001 ( $\$ 30$ trillion).

(ii) Most bonds are denominated in local currency. For the 46 economies in Tables 3 and 4, most bonds-91\% of advanced economy bonds and $87 \%$ of EME bonds-are denominated in local currency.

(iii) Bond markets are much larger in advanced economies (164\% of GDP) than in EMEs ( $32 \%$ of GDP), but they grew substantially in both. In advanced economies the size of local bond markets increased from being roughly equal to GDP in 2001 to being equivalent to 1.6 times GDP in 2011. Over the same period, the size of local bond markets in EMEs increased from $26 \%$ to $32 \%$ of GDP.

(iv) The value of local currency bonds in EMEs nearly doubled as a share of the total global bond market, rising from 5.1\% in 2001 to $8.6 \%$ in 2011.

(v) The share of EME bonds denominated in foreign currency fell from 25\% in 2001 to $13 \%$ in 2011-an unambiguously positive development, in our view.

(vi) The share of foreign currency-denominated bonds in developing Asia was only 7\% in 2011. Economies that still had a high proportion of foreign currency bonds included the Philippines (38\%) and Indonesia (26\%). In contrast, in the PRC, India, Malaysia, Pakistan, and Thailand, local currency-denominated bonds represented more than $90 \%$ of all bonds.

(vii) The development of local currency bond markets was particularly striking in Latin America. In 2001 nearly half of Latin American bonds were denominated in a foreign currency; by 2011 local currency bond markets had grown to the point where only a quarter of bonds in the region were issued in a foreign currency.

The evolution of global bond markets is evident in Figure 1. As a share of GDP, local currency bond markets are largest in advanced economies. EME bond markets are, on average, small (panel a). The structure of many EME bond markets improved dramatically over the past decade, however, with many reducing their reliance on foreign currency-denominated bonds (panel c). In sum, recent growth 
has been accompanied by a move toward an improved structure, but EME bond markets have room to grow.

In advanced economies (panel b), most bonds are denominated in local currency. In EMEs (panel d), most bonds are sovereign and denominated in local currency, although the value of private local currency-denominated bonds increased sharply between 2007 and 2011.

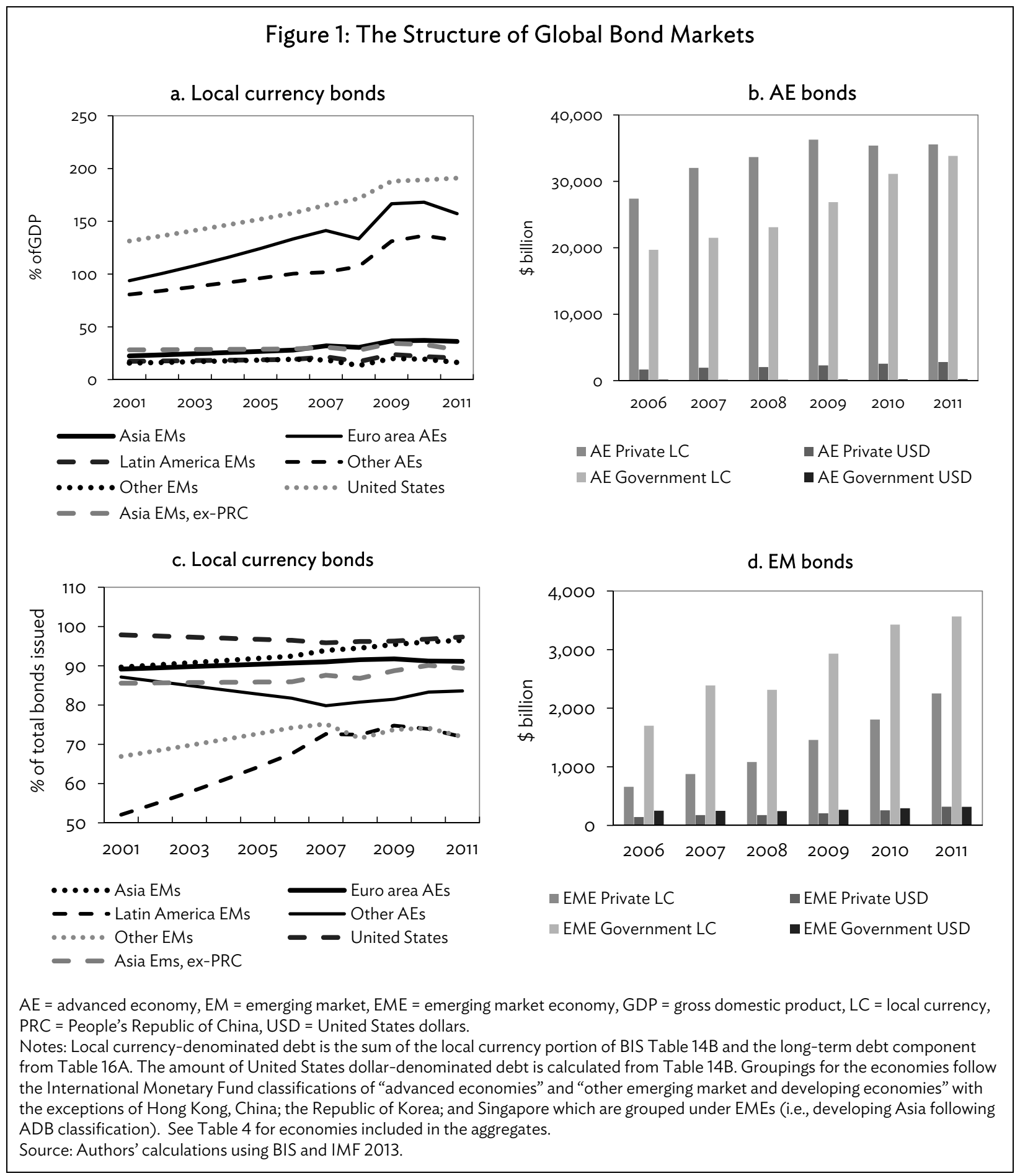




\section{FACTORS AFFECTING THE SIZE OF BOND MARKETS IN EMERGING MARKET ECONOMIES}

Why do some EMEs have larger local currency bond markets than others? According to the "original sin" hypothesis, some economies are just naturally larger than others. Nothing other than sheer size distinguishes one economy from another, and the bond markets of smaller economies would forever be inconsequential.

The evidence is not consistent with this hypothesis. Economies can (and have) put in place institutions and policies that foster the development of debt markets (Burger and Warnock 2006). Economies with better inflation performance (an outcome of creditor-friendly policies) have more developed local bond markets, both private and government, and rely less on foreign currencydenominated bonds. Creditor-friendly laws matter. Stronger rule of law is associated with deeper local bond markets, and economies with stronger creditor rights are able to issue a larger share of bonds in their local currencies.

Many studies corroborate these results; they include La Porta et al. (1997); Claessens, Klingebiel, and Schmukler (2007); Jeanne and Guscina (2006); Eichengreen and Luengnaruemitchai (2006); and Mehl and Reynaud (2005). Claessens, Klingebiel, and Schmukler find that government bond markets are larger in large economies with deeper domestic financial systems, lower inflation, larger fiscal deficits, stronger legal origins, and greater capital account openness. Eichengreen and Luengnaruemitchai find that larger size, stronger institutions, less volatile exchange rates, and more competitive banking sectors tend to be positively associated with bond market capitalization.

There are at least two caveats for the list of possible determinants of bond market development. As Burger and Warnock (2006) show, the fiscal balance result applies to government bond markets (everything else equal, larger fiscal deficits imply more government borrowing and hence larger government bond markets) but not to private bond markets, and bond markets and banking systems share some fundamental factors.

Burger, Warnock, and Warnock (2012) assess the size of local currency bond markets in 2008. As in previous studies, they find that EMEs with lower inflation volatility and stronger legal rights have more developed local bond markets (Figure 2). Macroeconomic stability (low inflation volatility) and strong creditor rights enable many positive developments in EMEs, including the development of their bond markets. Over the past decade, some countries with historically high and volatile inflation (such as Brazil and Mexico) made the macroeconomic policy adjustments necessary to bring inflation under control. In general, the local currency bond markets in these countries grew and reliance on foreign currency debt declined. Other EMEs, including Argentina, Pakistan, and the Russian Federation, had less success bringing inflation under control. They continue to have less developed and less attractive local currency bond markets.

\section{A. Determinants}

It is instructive to examine the regression results from Burger and Warnock (2006) on the factors behind local currency bond market development. This work analyzes two measures of local bond market development: the ratio of the size of the local bond market to GDP (local bond market development) and the share of the country's outstanding bonds denominated in the local currency (local currency share). Explanatory variables include the rule of law, creditor rights, the fiscal balance, 
country size, the growth rate, and inflation volatility. Creditor rights measure whether the laws of the country are creditor friendly; inflation volatility measures whether policies have been creditor friendly.

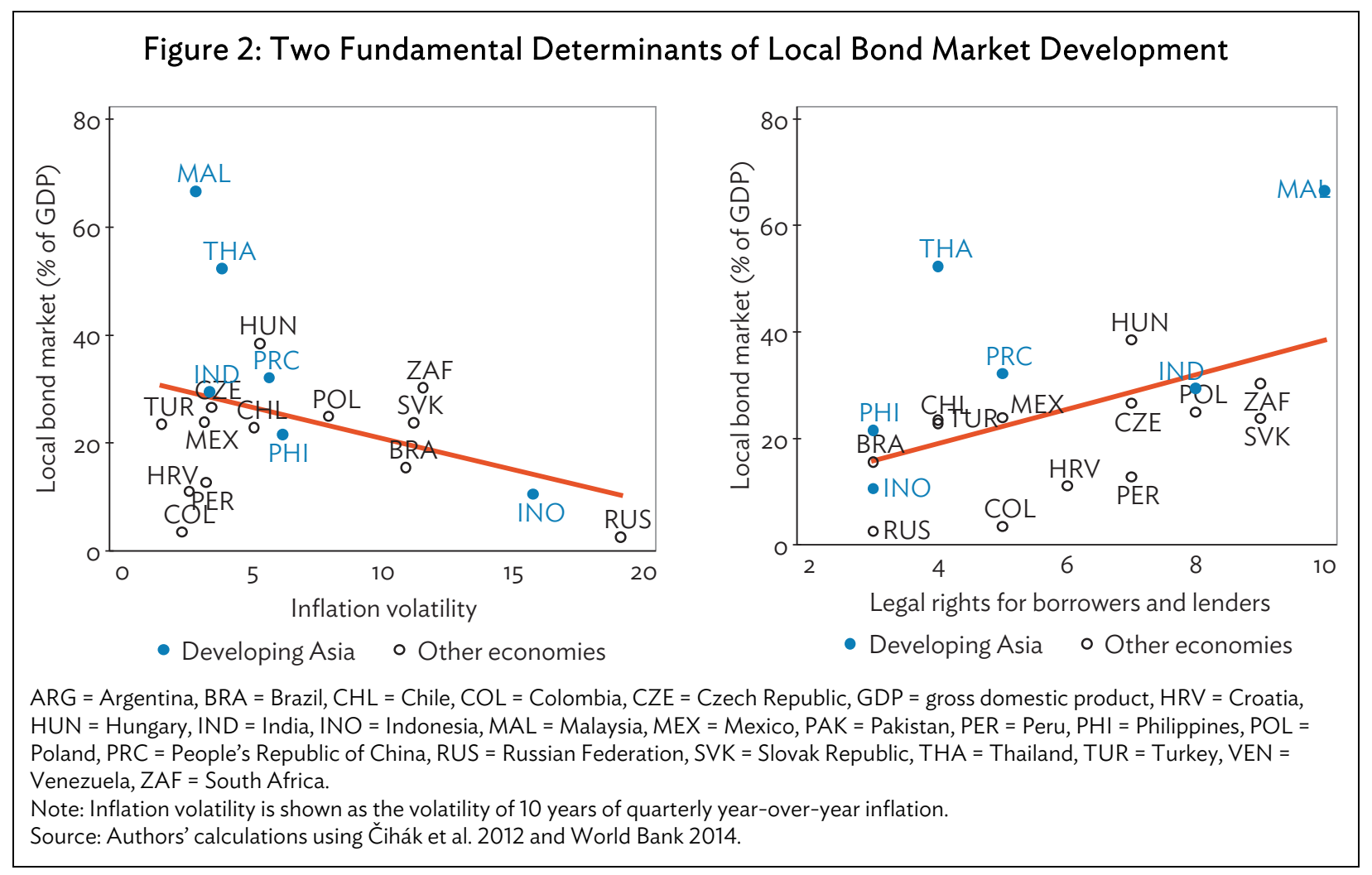

The evidence indicates that countries with better inflation performance (the result perhaps of more stable monetary and fiscal policies) have larger local currency bond markets and rely less on foreign currency bonds. It also suggests that countries with stronger institutions have broader local currency bond markets and that economies with stronger creditor rights rely less on foreign currency bonds. The determinants of the size of government and private bond markets are similar. The main difference is the influence of fiscal policy. A tendency to run fiscal deficits is associated with larger government bond markets (larger deficits require more government borrowing) but not larger private bond markets.

One concern about the baseline results is that virtuous interactions between the development of the bond market and future inflation performance suggest that inflation could plausibly be considered endogenous in bond market development regressions. At one level, inflation is endogenous: when a country has a well-developed bond market that many of its citizens use as a means to save, the government has an implicit promise to keep inflation under control (else savings be reduced in real terms). Concerns about the potential endogeneity of inflation are alleviated to some extent because inflation volatility is already a lagged measure and could be lagged even more without affecting the basic results. More formally, an instrumental variable approach could be used to address the potential endogeneity of inflation.

We instrumented for the mean of inflation (finding instruments for the variance proved difficult) using a measure of central bank independence and the fiscal balance. The fiscal balance would be endogenous to the development of government bond markets-larger deficits directly result 
in more government bonds outstanding-but should affect private bond market development only to the extent that it affects inflation. Similarly, the degree to which a central bank is independent should not directly affect private bond market development, but it may well do so through its impact on past and prospective inflation. The message is clear: even when instrumenting for inflation, countries with worse inflation performance have smaller local currency bond markets.

It is also important to consider the relationship between bond market and banking sector development. The conditions necessary for bond market development, such as creditor-friendly policies and laws, are similar to the conditions that foster the development of the banking system. Countries in which people are not willing to become creditors-at one extreme because they are unwilling to deposit money in banks - have undeveloped banking systems and underdeveloped bond markets. Countries with larger bond markets tend to have larger banking systems (but not larger stock markets). There is not a trade-off between bond market development and banking system development; the factors that foster both are similar.

Going forward, one would expect to see bond market development in countries with macroeconomic stability and strong creditor rights. Figure 2 provides some guidance for the future. The fact that Colombia, Croatia, and Peru score far better on both macroeconomic stability and legal rights than the size of their bond markets suggests may mean that their bond markets are poised for growth. In contrast, Brazil's bond market is close to its predicted size, suggesting that macroeconomic stability and creditor rights should improve before the market grows much more. Our estimates suggest that if Brazil were able to strengthen creditor rights to be the level of the Czech Republic (an increase in its legal rights index from 3 to 7), it could double the size of its local currency bond market. Significant growth in Brazil's market that is not accompanied by improvements in creditor rights and macroeconomic stability should be viewed with caution.

\section{B. Caveats}

Bond markets are not immune to instability. In the past, one source of instability was currency mismatches. That risk has diminished as a result of reduced reliance on foreign currency borrowing.

Not all developments in bond markets have been benign, however. Some bond markets, especially in advanced economies, grew too rapidly. For example, Ireland's euro-denominated bond market grew by a factor of 10 in just 7 years, rising from 46\% of GDP in 2001 to 336\% in 2008. This increase proved unsustainable; Ireland is still paying for its unbridled bond market growth. The size of Iceland's local currency bond market soared from 91\% of GDP in 2001 to 396\% by 2006. Over this period, $40 \%$ of its bonds were denominated in foreign currency. As a result of the 2008 depreciation, crisis, and defaults, its bond market shrunk to 104\% of GDP (although the currency mismatch did not immediately improve). Although EME bond markets fared better in the past decade, economies must remain wary of unsustainable growth and of developing currency mismatches.

Another concern is that alleviating one mismatch (currency) may exacerbate another (maturity). This concern may be unwarranted: Burger, Warnock, and Warnock (2012) show that reduced reliance on foreign currency borrowing was not replaced by greater reliance on short-term borrowing. Average local currency bond maturities generally increased over the past decade, with impressive lengthening in Latin America.

The work of developing bond markets is never over. High and volatile inflation smothers bond markets (and borrowing and lending in general). Any surge in inflation therefore merits close attention. 
If an increase is contained and proves short-lived, local currency bond markets will not be adversely affected. If, however, a spike turns into persistently high and volatile inflation, progress could quickly reverse.

\section{INSIGHTS INTO DEVELOPING ASIA'S BOND MARKETS}

Data for the larger Asian economies are available from Asian Bonds Online along two dimensions: the size of the local currency bond market as a percent of GDP and the share of foreign currency bonds in total bonds. These data indicate that the PRC's local currency bond market grew from about $5 \%$ of GDP in 1997 to 50\% of GDP by the end of 2013 and that its share of foreign currency bonds was low, at about 5\% (Figure 3). Local currency bond markets were largest in the Republic of Korea (120\% of GDP) and Malaysia (110\%). Most economies did not display currency mismatches, with most foreign currency shares below 10\%. One exception was Hong Kong, China. Its 40\% foreign currency share would be considered very high were it not for its peg to the US dollar and its significant US dollar export revenues.

As an illustrative example of financial stability issues related to bond market development, consider the Philippines and Viet Nam, two economies in which reliance on foreign currency bonds declined significantly in recent years. The foreign currency share of the bond market fell from $45 \%$ to $30 \%$ in the Philippines and from 100\% to just 10\% in Viet Nam. Reduced foreign currency borrowing should improve financial stability by reducing vulnerability to exchange rate shocks, but it raises the question of whether the currency mismatch is being replaced by a maturity mismatch.

Figure 4 shows the share of sovereign local currency bonds with maturities greater than 10 years as a proxy for the evolving maturity structure in the Philippines and Viet Nam. It reveals a striking contrast. The Philippines reduced foreign currency borrowing and expanded the share of long-term bonds. In contrast, Viet Nam's increased local currency issuance was coupled with a reduction in the share of long-term bonds. About two-thirds of its local currency bonds have maturities of 1 to 3 years, suggesting that Viet Nam may have replaced its currency mismatch with a maturity mismatch, leaving it vulnerable to changes in financing conditions.

The Asian Bonds Online data are useful, but like the BIS data, they are available only for the larger developing Asian economies. The financial structure of the smaller developing economies is quite different: the median bond market size in the 42 economies is zero.

To assess factors that could enable bond market development in the smaller economies, we merge what we have learned from the statistical analyses in our previous papers with World Bank data on bond market size as well as two fundamental factors in bond market development. Alongside data on the size of public and private bonds outstanding, (both expressed as a percentage of GDP) from the World Bank's Financial Structure database, Table 5 shows data on two fundamental factors of local currency bond market development: inflation volatility and the legal rights of borrowers and lenders (World Bank 2014). In advanced economies and larger EMEs, stronger legal rights for borrowers and lenders and lower inflation volatility are associated with larger local currency bond markets (see Figure 2). Formal analysis of the 42 developing economies in Asia is limited by the fact that the vast majority lack a bond market of any size. Nonetheless, descriptive analysis suggests that inflation volatility plays an important role in explaining the cross-sectional variation in bond market development. For example, historical inflation volatility is on average twice as high in the developing Asian economies that lack bond markets than in the developing Asian economies that have them. 


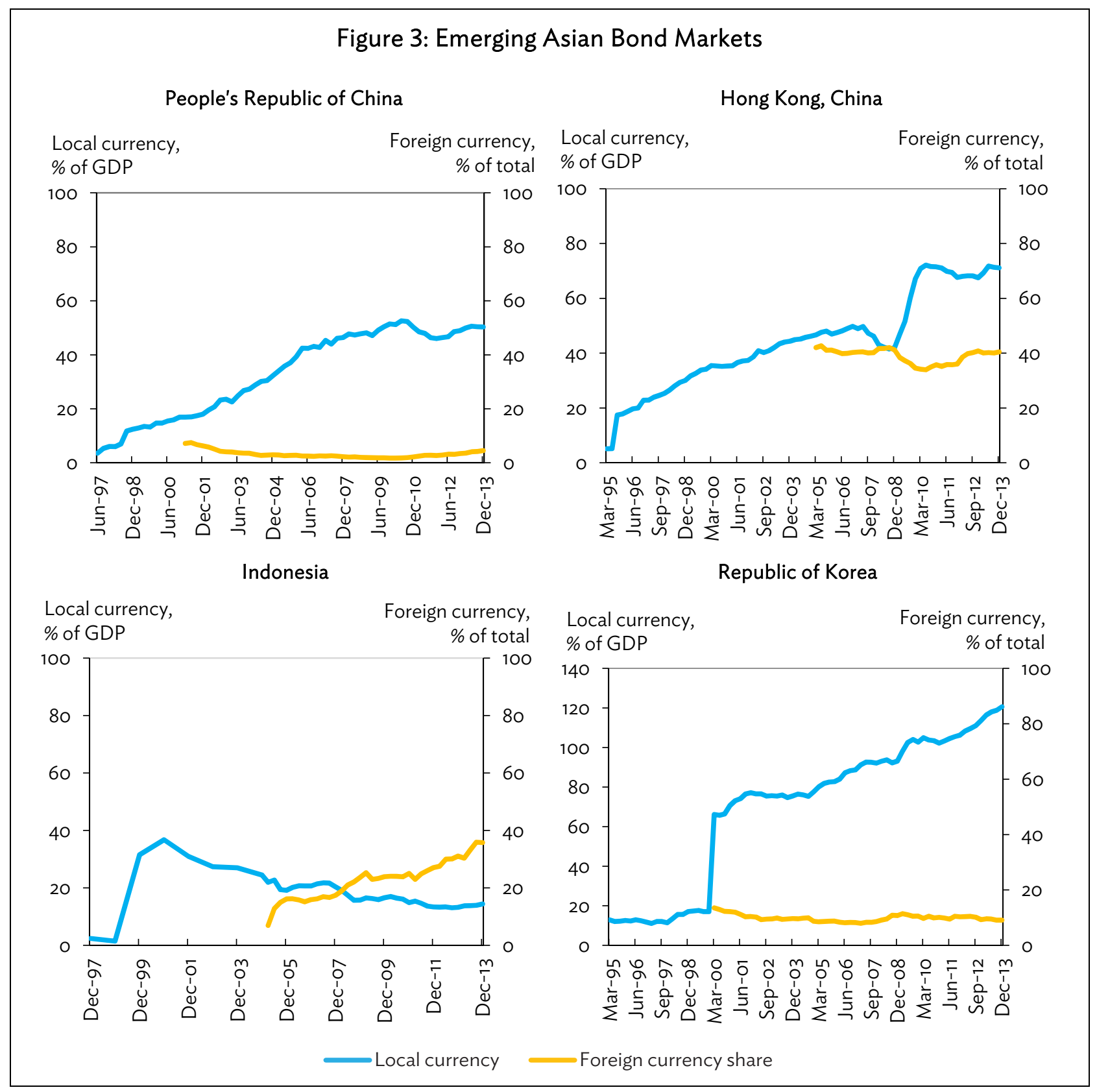


Figure 3 continued

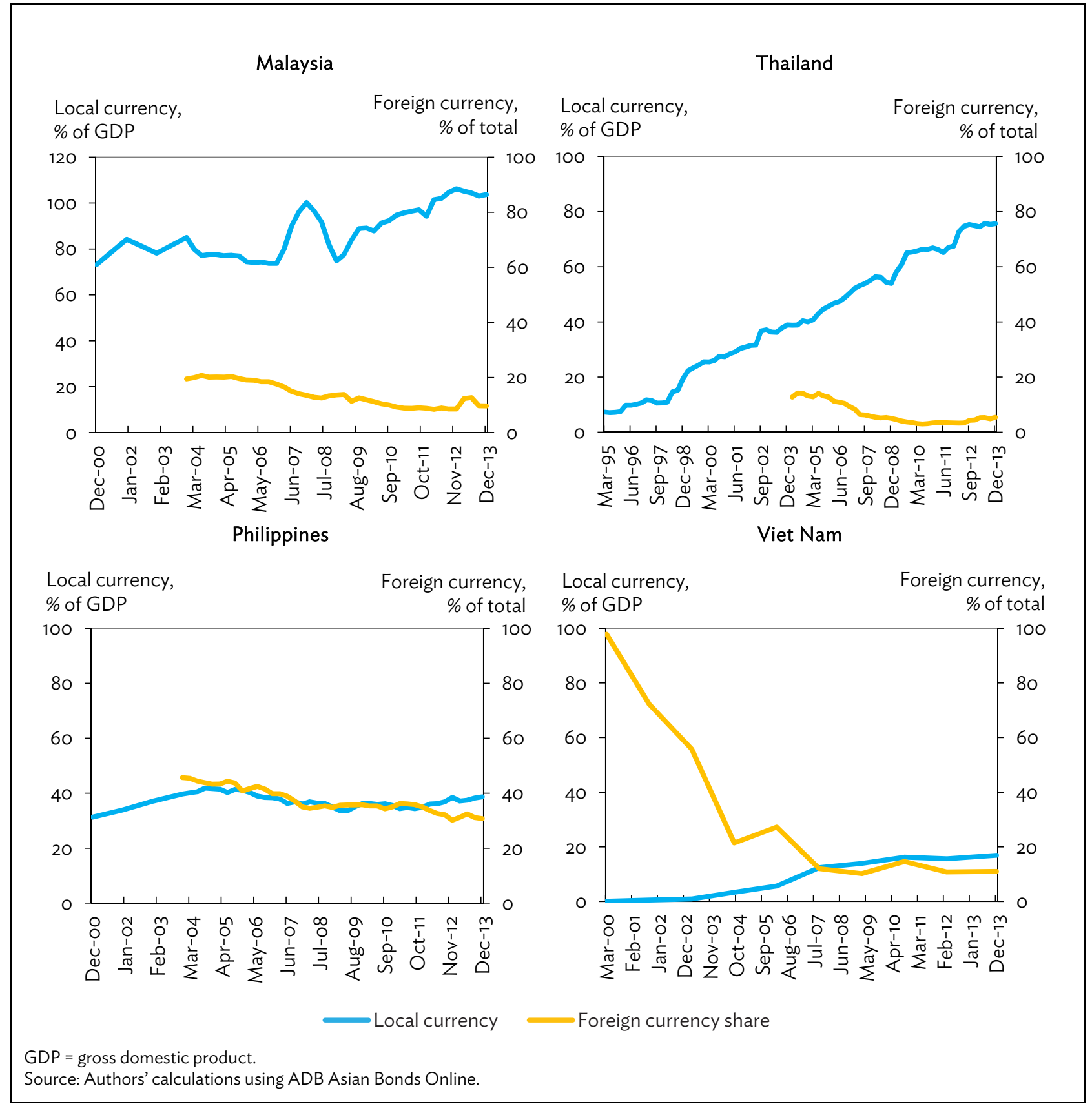



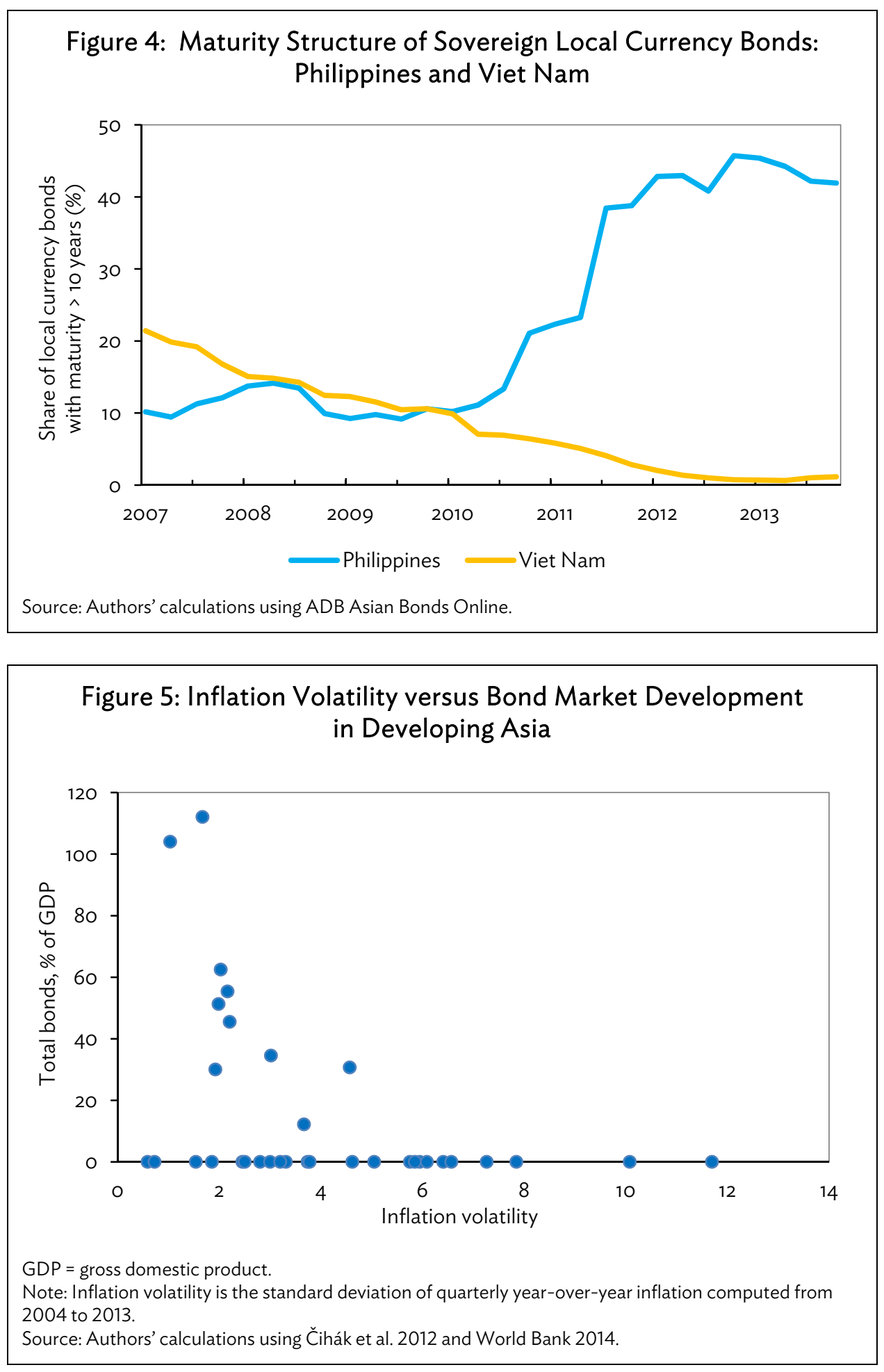

Figure 5 presents a scatterplot of a negative and statistically significant relationship between inflation volatility and bond market development. The data suggest a concrete policy prescription: economies with high inflation volatility could spur bond market development by reducing that volatility. Such economies include but are not limited to Afghanistan, Cambodia, the Kyrgyz Republic, Mongolia, and Myanmar. 
Table 5: Developing Asian Bond Markets and Fundamental Factors

\begin{tabular}{|c|c|c|c|c|c|}
\hline Economy & Weights & $\begin{array}{l}\text { Public } \\
\text { Bonds }\end{array}$ & $\begin{array}{l}\text { Private } \\
\text { Bonds }\end{array}$ & $\begin{array}{l}\text { Inflation } \\
\text { Volatility }\end{array}$ & Legal Rights \\
\hline Developing Asia & & 25.7 & 20.4 & & \\
\hline Central Asia & 0.01 & 0.0 & 0.0 & & \\
\hline Armenia & 0.06 & 0.0 & 0.0 & 3.3 & 5 \\
\hline Azerbaijan & 0.00 & 0.0 & 0.0 & 6.4 & 2 \\
\hline Georgia & 0.07 & 0.0 & 0.0 & 4.6 & 9 \\
\hline Kazakhstan & 0.84 & 0.0 & 0.0 & 3.7 & 3 \\
\hline Kyrgyz Republic & 0.00 & 0.0 & 0.0 & 7.8 & 8 \\
\hline Tajikistan & 0.03 & 0.0 & 0.0 & 0.6 & 1 \\
\hline Turkmenistan & 0.00 & 0.0 & 0.0 & & \\
\hline Uzbekistan & 0.00 & 0.0 & 0.0 & & 1 \\
\hline East Asia & 0.64 & 25.9 & 27.8 & & \\
\hline People's Republic of China & 0.83 & 22.4 & 23.1 & 2.2 & 4 \\
\hline Hong Kong, China & 0.03 & 36.0 & 15.3 & 2.0 & 7 \\
\hline Republic of Korea & 0.14 & 44.8 & 59.3 & 1.0 & 5 \\
\hline Mongolia & 0.00 & 0.0 & 0.0 & 6.6 & 5 \\
\hline South Asia & 0.18 & 27.0 & 4.0 & & \\
\hline Afghanistan & 0.01 & 0.0 & 0.0 & 10.1 & 9 \\
\hline Bangladesh & 0.05 & 0.0 & 0.0 & 1.9 & 6 \\
\hline Bhutan & 0.00 & 0.0 & 0.0 & 2.5 & 4 \\
\hline India & 0.83 & 29.6 & 4.9 & 3.0 & 6 \\
\hline Maldives & 0.00 & 0.0 & 0.0 & 5.8 & 2 \\
\hline Nepal & 0.01 & 0.0 & 0.0 & 2.8 & 7 \\
\hline Pakistan & 0.08 & 30.7 & 0.0 & 4.6 & 3 \\
\hline Sri Lanka & 0.02 & 0.0 & 0.0 & 5.9 & 3 \\
\hline Southeast Asia & 0.16 & 28.3 & 11.8 & & \\
\hline Brunei Darussalam & 0.01 & 0.0 & 0.0 & 0.7 & 4 \\
\hline Cambodia & 0.01 & 0.0 & 0.0 & 7.3 & 11 \\
\hline Indonesia & 0.39 & 10.8 & 1.4 & 3.7 & 4 \\
\hline Lao PDR & 0.00 & 0.0 & 0.0 & 3.0 & 7 \\
\hline Malaysia & 0.13 & 54.0 & 58.1 & 1.7 & 7 \\
\hline Myanmar & 0.00 & 0.0 & 0.0 & 11.7 & 2 \\
\hline Philippines & 0.11 & 29.1 & 1.0 & 1.9 & 3 \\
\hline Singapore & 0.12 & 45.4 & 10.0 & 2.2 & 8 \\
\hline Thailand & 0.17 & 49.8 & 12.7 & 2.0 & 3 \\
\hline Viet Nam & 0.06 & 0.0 & 0.0 & 6.1 & 7 \\
\hline The Pacific & 0.00 & 0.0 & 0.0 & & \\
\hline Fiji & 0.20 & 0.0 & 0.0 & 2.5 & 5 \\
\hline Kiribati & 0.00 & 0.0 & 0.0 & & 4 \\
\hline Marshall Islands & 0.00 & 0.0 & 0.0 & & 10 \\
\hline Federated States of Micronesia & 0.00 & 0.0 & 0.0 & & 11 \\
\hline Palau & 0.00 & 0.0 & 0.0 & & 10 \\
\hline Papua New Guinea & 0.60 & 0.0 & 0.0 & 3.2 & 3 \\
\hline Samoa & 0.04 & 0.0 & 0.0 & 5.9 & 5 \\
\hline Solomon Islands & 0.04 & 0.0 & 0.0 & 5.1 & 10 \\
\hline Timor-Leste & 0.05 & 0.0 & 0.0 & & 0 \\
\hline Tonga & 0.02 & 0.0 & 0.0 & 3.8 & 10 \\
\hline Tuvalu & 0.00 & 0.0 & 0.0 & & \\
\hline Vanuatu & 0.04 & 0.0 & 0.0 & 1.5 & 10 \\
\hline
\end{tabular}

GDP = gross domestic product, Lao PDR = Lao People's Democratic Republic.

Notes: Inflation volatility is shown as the standard deviation of quarterly year-over-year inflation computed from 2004 to 2013 . The legal rights measure for borrowers and lenders is scored from 0 (poor) to 12 (best).

Source: Authors' calculations using data from Beck, Demirgüç-Kunt, and Levine (2000, 2009); Čihák et al.2012; and World Bank 2014. 
Our empirical work did not find a statistically significant relationship between bond market development and legal rights in developing Asia. Earlier studies do find an important role for creditor rights, however (Burger and Warnock 2006). Economies that score low on legal rights for borrowers and lenders (perhaps below 6) could strengthen those rights to enable bond market development. Such economies include but are not limited to Azerbaijan, the Maldives, Myanmar, Pakistan, Papua New Guinea, the Philippines, Tajikistan, Thailand, and Uzbekistan.

\section{CONCLUSION}

This paper provides a descriptive analysis of the structure of financial systems (banking systems and stock and bond markets) in emerging Asia and (for comparison) other regions. It brings together bond market data from the BIS, the World Bank, and ADB. Most analyses of bond markets use only data on advanced economies and the largest developing economies. This analysis includes data on 42 smaller Asian economies, where the median size of the bond market is zero.

The lessons of our past analyses of bond market development are applicable to developing Asia. They suggest that historically high inflation volatility presents a serious obstacle to bond market development. Smaller developing Asian economies could enable bond market development by pursuing creditor-friendly policies (for example, stabilizing inflation) and strengthening the legal rights of borrowers.

The larger EMEs in Asia have experienced impressive development of their local currency bond markets, which should contribute to continued growth and financial stability. They have reduced their reliance on foreign currency borrowing, thereby making their financial systems more resilient. Maturity mismatches have not replaced currency mismatches in most cases; most major Asian EMEs have demonstrated their ability to borrow long-term in local currency. Viet Nam provides a notable exception and perhaps a cautionary tale. It recently developed a local currency bond market and has greatly reduced its reliance on foreign currency bonds, but the vast majority of its local currency bonds have maturities of 1 to 3 years. Further progress on creditor-friendly policies and institutions will likely be necessary before Viet Nam is able to borrow long-term in its own currency. 


\section{REFERENCES}

Bank for International Settlements (BIS). Debt Securities Statistics. http://www.bis.org/statistics/ secstats.htm?m=6\%7C33

Beck, T., A. Demirgüç-Kunt, and R. Levine. 2000. A New Database on Financial Development and Structure. World Bank Economic Review. 14 (3). pp. 597-605.

- - . 2009. Financial Institutions and Markets across Countries and over Time: Data and Analysis. World Bank Policy Research Working Paper No. 4943. Washington, DC: World Bank.

Burger, J. D. and F. E. Warnock. 2006. Local Currency Bond Markets. IMF Staff Paper No. 53 (Special Issue). pp. 133-46.

Burger, J. D, F. Warnock, and V. Warnock. 2012. Emerging Local Currency Bond Markets. Financial Analysts Journal. 68 (4). pp. 73-93.

Caballero, R., E. Farhi, and P.-O. Gourinchas. 2008. An Equilibrium Model of Global Imbalances and Low Interest Rates. American Economic Review. 98 (1). pp. 358-93.

Čihák, M., A. Demirgüç-Kunt, E. Feyen, and R. Levine. 2012. Benchmarking Financial Development around the World. World Bank Policy Research Working Paper No. 6175. Washington, DC: World Bank.

Claessens, S., D. Klingebiel, and S. L. Schmukler. 2007. Government Bonds in Domestic and Foreign Currency: The Role of Institutional and Macroeconomic Factors. Review of International Economics. 15 (2). pp. 370-413.

Eichengreen, B. and R. Hausmann. 1999. Exchange Rates and Financial Fragility. In New Challenges for Monetary Policy. Kansas City, MO: Federal Reserve Bank of Kansas City.

- - . 2005. Other People's Money: Debt Denomination and Financial Instability in Emerging Market Economies. Chicago: University of Chicago Press.

Eichengreen, B. and P. Luengnaruemitchai. 2006. Why Doesn't Asia Have Bigger Bond Markets? BIS Paper No. 30. Basel: Bank for International Settlements.

Gruić, B. and P. Wooldridge. 2012. Enhancements to the BIS Debt Securities Statistics. BIS Quarterly Review. December. pp. 63-76.

International Monetary Fund (IMF). 2013. World Economic Outlook Statistical Appendix (April). http://www.imf.org/external/pubs/ft/weo/2013/01/pdf/statapp.pdf

Jeanne, O. and A. Guscina. 2006. Government Debt in Emerging Market Countries: A New Data Set. IMF Working Paper No. 06/98 (April). Washington, DC: International Monetary Fund.

La Porta, R., F. Lopez-de-Silanes, A. Shleifer, and R. W. Vishny. 1997. Legal Determinants of External Finance. Journal of Finance. 52 (3). pp. 1131-50. 
Levine, R. 2005. Finance and Growth: Theory and Evidence. In Phillipe Aghion and Steven N. Durlauf, eds. Handbook of Economic Growth. Amsterdam: Elsevier.

-_- 2008. Finance and the Poor. The Manchester School. 76 (1). pp. 1-13.

Mehl, A. and J. Reynaud. 2005. The Determinants of Domestic Original Sin in Emerging Market Economies. ECB Working Paper No. 560 (December). Frankfurt: European Central Bank.

World Bank. 2014. Doing Business 2015: Going Beyond Efficiency. Washington, DC. 


\section{Bond Market Development in Developing Asia}

The paper compares salient features of bond market development in developing Asia and other regions. It highlights key drivers and constraints of bond market development in developing Asia, particularly in smaller economies, as well as key implications for policy makers.

\section{About the Asian Development Bank}

ADB's vision is an Asia and Pacific region free of poverty. Its mission is to help its developing member countries reduce poverty and improve the quality of life of their people. Despite the region's many successes, it remains home to the majority of the world's poor. ADB is committed to reducing poverty through inclusive economic growth, environmentally sustainable growth, and regional integration.

Based in Manila, ADB is owned by 67 members, including 48 from the region. Its main instruments for helping its developing member countries are policy dialogue, loans, equity investments, guarantees, grants, and technical assistance.

$\mathrm{ADB}$ 